\title{
RATUSZE WIELKICH MIAST PRUS KRÓLEWSKICH W PUBLICZNYCH ŚWIĘTACH WŁADZY W XVI-XVIII WIEKU. UWAGI NA MARGINESIE PROJEKTU BADAWCZEGO*
}

Sięgając do opublikowanych w ostatnich dekadach prac poświęconych reprezentacyjnym, ceremonialnym funkcjom ratuszy w Europie Północnej, w tym i w wielkich miastach Prus Królewskich, czyniłem to nie bez obawy, że niewiele nowego na ten temat można napisać. Niemniej lektura m.in. skądinąd bardzo interesującej syntetycznej pracy Susan Tripton z 1996 r., Res publica bene ordinata ${ }^{1}$, poświęconej symbolice malarskich dekoracji ratuszowych, czy ponowne zapoznanie się ze zbiorem studiów Ratusz w miastach pótnocnej Europy z 1997 r. ${ }^{2}$ dowodzi, że sporo zagadnień, szczególnie tych wymagających kompetencji interdyscyplinarnych, nie doczekało się jeszcze dostatecznej analizy badawczej3․ Wybór tematu, którego celem jest omówienie i porównanie

* E. Kizik, W. Kriegseisen, „Święto władzy. Ceremonie publiczne w wielkich miastach Prus Królewskich w XVI-XVIII wieku. Studium z kształtowania się nowożytnej kultury ceremonialnej" - projekt badawczy przygotowywany w Instytucie Historii PAN.

${ }^{1} \mathrm{~S}$. Tripton, Res publica bene ordinata. Regentenspiegel und Bilder vom guten Regiment. Rathausdekorationen in der Frühen Neuzeit, Hildesheim 1996.

${ }^{2}$ Ratusz w miastach pótnocnej Europy. Materiaty z sesji „Ratusz w miastach nadbattyckich”, Gdańsk 23-25 XI 1993, red. S. Latour, Gdańsk 1997.

${ }^{3}$ Najpoważniejsze prace dla Gdańska: I. Fabiani-Madeyska, Palatium regium w Gdańsku, „Rocznik Gdański” 15/16, 1956/1957, s. 140-198; taż, Gdzie rezydowali $w$ Gdańsku królowie polscy?, Gdańsk 1976; przegląd literatury zob. E. Kizik, Koszty pobytu królów polskich $w$ Gdańsku $w$ XVII w. Rekonesans badawczy, KH 114, 2007, nr 4, s. 61-77. Dla Torunia: Imprezy towarzyskie $i$ oficjalne $w$ dawnym Toruniu, red. J. Staszewski, Toruń 1994; niewielkie opracowanie bez aparatu naukowego, Królowie polscy $w$ Toruniu, red. M. Biskup, Toruń 1984, nosi charakter popularny. Dla Elblaga zob. podstawowe opracowanie: L. Neubaur, Zur Geschichte des sogenannten Königshauses in Elbing, „Zeitschrift des Westpreussischen Geschichtsvereins” 59, 1919, s. 115-133. Z opracowań dla mniejszych miast pruskich: J.M. Krzemiński, Od Sasa do 
funkcji ceremonialnych ratuszy w trzech wielkich miastach pruskich: w Gdańsku, Elblagu i w Toruniu, pozwoliło mi na poczynienie kilku spostrzeżeń badawczych, którymi chciałbym się z czytelnikiem podzielić. Niniejsze uwagi zwiazane sa z monograficznym projektem badawczym, którego celem jest kompleksowa rekonstrukcja uroczystości publicznych w wielkich miastach Prus Królewskich od przełomu XV i XVI w. aż po początki XIX w., na tle zwyczaju ceremonialnego oraz rozwoju uczonej wiedzy ceremonialnej epoki nowożytnej: w Prusach, w Polsce, cesarstwie oraz w kręgu kultury hanzeatyckiej ${ }^{4}$.

$$
* * *
$$

Za podstawę źródłową poza starodrukami ${ }^{5}$ oraz literaturą przedmiotu posłużyły mi rękopiśmienne źródła archiwalne z Archiwum Państwowego w Gdańsku, tzw. solemnia lub ceremonialia ${ }^{6}$, czyli ustalane przez władze miejskie szczegółowe scenariusze obchodów, jak również wybrane recesy, czyli protokoły posiedzeń gdańskich ordynków ${ }^{7}$. W wypadku Elblaga z powodu zaginięcia - poza nieurzędowym zespołem rękopisów elbląskich $^{8}$ - większości recesów rady sprzed XVIII w., ważnym uzupełnieniem są wyciagi z protokołów rady ${ }^{9}$ Szczególnie dla Gdańska ${ }^{10}$,

Sasa. Królewskie popasy w Malborku. Z kroniki malborskiej rezydencji Jezuitów, „Rocznik Gdański” 45, 1985, nr 1, s. 173-194.

${ }^{4}$ Inspirujące dla autorów projektu są m.in. prace: T. Weller, Theatrum Praecedentiae. Zeremonieller Rang und gesellschaftliche Ordnung in der frühneuzeitlichen Stadt. Leipzig 1500-1800, Darmstadt 2006; zbiory studiów: Soziale und ästhetische Praxis der höfischen Fest-Kultur im 16. und 17. Jahrhundert, red. K. Dickhaut [i in.], Wiesbaden 2009; Hofwirtschaft. Ein ökonomischer Blick auf Hof und Residenz in Spätmittelalter und Früher Neuzeit, red. G. Fouquet, Ostfildern 2008. Zob. również A. Gugler, Feiern und feiern lassen. Festkultur am Wiener Hof in der zweiten Hälfte des 16. und der ersten Hälfte des 17. Jahrhunderts, „Früheneuzeit-Info” 11, 2000, nr 1, s. 68-176; Europa Triumphans. Court and Civic Festivals in Early Modern Europe, red. J.R. Mulryne [i in.], London 2004.

${ }^{5}$ Bibliografia druków zawierających relacje z ceremonialnych wjazdów: E. Kotarski, Ikonosfera w kulturze dawnego Gdańska. Zarys problematyki, „Libri Gedanenses” 11/12, 1993/1994, s. 41.

${ }^{6}$ Archiwum Państwowe w Gdańsku (dalej: APGd.), 300, R/4.

${ }^{7}$ APGd., 300, 10; zob. C. Biernat, Recesy gdańskich ordynków 1545-1814, Gdańsk 1958, na s. 39-45 podstawowe wskazówki dot. struktury zachowanego materiału źródłowego, wyciagów tematycznych i innych pomocy archiwalnych.

${ }^{8}$ APGd., 492/451 (podstawowy zespół, zawierający również liczne druki okazjonalne).

${ }^{9}$ APGd., 369, 1/104, t. 1-2; 369, 1/108-110 (hasła w układzie alfabetycznym).

${ }^{10}$ Materiał archiwalny pod tym kątem analizowałem m.in. w artykułach: Koszty pobytu królów... i Wynagrodzenia za dzieła dedykowane lub ofiarowane Radzie 
ale również i dla Elblaga ${ }^{11}$, przetrwały dostatecznie bogate materiały z miejskich kamlarii, co pozwala na obserwację ekonomicznej strony organizacji wydarzeń uroczystych. Lecz wymaga to uważnej korelacji z materiałami innego pochodzenia; na ich dokładniejszą analizę nie ma miejsca w niniejszym tekście. Jeśli chodzi o Toruń, to niestety źródła kamlarskie zachowały się jedynie $\mathrm{w}$ niewielkim stopniu ${ }^{12}$, dlatego na tym etapie ograniczyłem się przede wszystkim do analizy starodruków dostępnych w Bibliotece Gdańskiej PAN ${ }^{13}$. Nie badano również jeszcze zbiorów Sztokholmu i Uppsali celem odnalezienia opisów ceremonii w Elblagu i Toruniu z okresu okupacji tych miast przez wojska szwedzkie w XVII i początku XVIII w. czy materiałów rosyjskich dokumentujących pobyty w Elblagu m.in. cara Piotra I i innych członków rodziny Romanowów w 1. połowy XVIII w. Owocne okazało się sięgnięcie do oficjalnych uczonych poradników wiedzy ceremonialnej z XVIII w., spisanych przez ówczesne autorytety w tych dziedzinach, czyli Johanna Christiana Lüniga Theatrum ceremoniale historico-politicum (1719$-1720)^{14}$, dzieła zadedykowanego Johannowi Georgowi Flemmingowi, ministrowi króla Augusta II, oraz Teutsches Hof-Recht Friedricha Carla von Mosera z 1754 r. ${ }^{15}$ Kodeksy te, tylko sporadycznie wykorzystywane

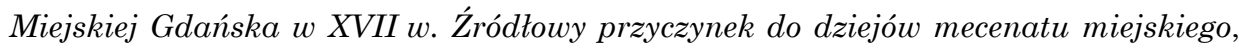
„Rocznik Biblioteki Narodowej” 2012, s. 75-85; analizę z punktu widzenia historyka sztuki przedstawił J. Kriegseisen, Sztuka w polityce miasta. Zamówienia artystyczne Gdańska w czasach Bartholomäusa Milwitza, w: Gdańsk w epoce Bartholomäusa Milwitza, red. E. Kizik, Gdańsk 2010, s. 56-65.

${ }^{11}$ APGd., 369, 1/ 668-690; 1383-1503 (ten obszerny materiał analizowałem wstępnie jedynie dla wybranych lat budżetowych: 1626-1627: APGd., 369,1/1418; 1734 -1736: APGd., 369, 1/1726-1727 oraz 1764-1765: APGd., 369, 1/1502).

${ }^{12}$ Wszelako nawet szczątkowo zachowane źródła pozwalają na bardzo interesujące ustalenia związane z rolą podarków ceremonialnych, zob. B. Łyczak, Łyżki, morselki $i$ kantaty. Osiemnastowieczne upominki na kiere $i$ Nowy Rok $w$ Toruniu i innych miastach Prus Królewskich, KHKM 60, 2012, nr 1, s. 33-48.

${ }^{13}$ Fundamentalnym źródłem pozostaje kronika nieszczęsnego burmistrza Jacoba Heinricha Zerneckego, Historiae Thoruniensis naufragae tabulae, oder Kern der Thornischen Chronicke, Thorn 1711, np. przyjazdy królów opisane są na s. 90, 94, 106, 136, 174, 196, 205, 219, 268, 273, 279, 290, 314, 327, 347, 349, 356, 357, 410, 421; ceremonie żałobne po śmierci królów: s. 286, 319, 321, 399.

${ }^{14}$ J.Ch. Lünig, Theatrum Ceremoniale historico-politicum oder historisch- und politischer Schau-Platz aller Ceremonien, welche so wohl an Europäischen Höfen, als auch sonsten bey vielen Illustren Fällen beobachtet worden [...] Nebst [...] Dem Europäischen Cantzley-Ceremoniel, Elenchis und Registern, Leipzig 1719; tam m.in. opisy wjazdu Augusta II do Gdańska i Lwowa w 1698 r. oraz szczegóły dot. ceremoniału polskiego: s. 356-360, 498, 1131 i n., s. 94, 95.

${ }^{15}$ F.C. von Moser, Teutsches Hof-Recht in zwölf Büchern, t. 1-2, Frankfurt-Leipzig 1754-1761. Zob. omówienie literatury ceremonialnej 2. poł. XVII i XVIII w.: J. Falcke, 
przez polskich badaczy, opisują oraz systematyzuja dworskie zachowania ceremonialne i dyplomatyczne z XVI - początku XVIII w., stanowiąc również świadectwo rosnącego znaczenia etykiety dyplomatycznej oraz ceremonii publicznej w kształtowaniu relacji pomiędzy władcami i poddanymi.

Pozostajemy przede wszystkim w sferze źródeł pisanych, albowiem poza malarskimi i graficznymi przedstawieniami wjazdów władców do miast pruskich ${ }^{16}$ pozostałe źródła ikonograficzne ukazujace przebieg i scenariusze ceremonii zachowały się w dość znikomym stopniu ${ }^{17}$.

\section{Uroczystości ceremonialne}

Zanim przejdę do roli ratusza w wydarzeniach ceremonialnych, postaram się nieco bliżej sprecyzować samo pojęcie stanowiace przedmiot rozważań. Pod tytułowym określeniem ,święta władzy” rozumiem zespół publicznych - okazjonalnych, rzadziej cyklicznych - zachowań ceremonialnych, które miały na celu propagandowe podkreślenie i uczczenie pewnego wydarzenia dziejącego się współcześnie lub upamiętnienie zdarzenia z przeszłości. Wydarzeniu takiemu w opinii publicznej nadaje się rangę nadzwyczajności - co dodatkowo zaakcentowane jest poprzez obecność i autorytet reprezentantów władzy i polityki, nauki i religii - a nadzwyczajność ta zobowiązuje do odpowiedniego zorganizowania obchodów świątecznych. Wspólny i z zasady powszechny udział społeczności miejskiej w takich wydarzeniach ceremonialnych służył w istotny sposób utrzymaniu oraz dodatkowemu podkreśleniu panującego porządku społecznego oraz spójności danego społeczeństwa.

Studien zum diplomatischen Geschenkwesen am brandenburgisch-preußischen Hof im 17. und 18. Jahrhundert, Berlin 2006 (Quellen und Forschungen zur Brandenburgischen und Preußischen Geschichte, 31), s. 19-26; por. moją recenzję tej ważnej pracy: „Zapiski Historyczne” 73, 2008, nr 2-3, s. 219-225.

${ }^{16}$ Zob. J.A. Chrościcki, Intrada z roku 1646 jako przykład zwiazków artystycznych Gdańska z Antwerpia, w: Sztuka pobrzeża Battyku, Warszawa 1978, s. 309-340; T. Fabijańska-Żurawska, Ceremonialne wjazdy paradne $w$ Polsce $w$ XVII wieku, w: Królewskie karety Jana III Sobieskiego. Katalog wystawy, Muzeum Pałac w Wilanowie, red. E. Birkenmajer, A. Kwiatkowska, Warszawa 2003, s. 31-62; cenna ze względu na możliwości porównawcze jest praca A. Śliwowskiej, Uroczyste wjazdy monarsze do Wrocławia w latach 1527-1620, Wrocław 2008.

${ }^{17}$ Najważniejsze przedstawienia powstały w związku z wjazdem do Gdańska królowej Ludwiki Marii Gonzagi w 1646 r., zob. J. Tylicki, Bartłomiej Milwitz - aspekty twórczości, w: Gdańsk w epoce Bartholomäusa Milwitza, red. E. Kizik, Gdańsk 2010, s. 66-82, szczególnie s. 73-75; tam również literatura przedmiotu. 
Udział w ceremonii stanowił kolegialny i powszechny w swej istocie wyraz wspólnych wartości oraz uczuć, służąc zademonstrowaniu i przypomnieniu zebranym poddanym hierarchii miejscowej władzy.

Uroczystości odznaczaja się wysokim stopniem sformalizowania, przebiegają w wyznaczonej przestrzeni i w konkretnym czasie, uczestnikom oraz widzom narzucone sa ściśle określone reguły zachowań, wypowiedzi oraz ubioru. Z reguły ceremonie charakteryzuje rytualne uporządkowanie oraz powtarzanie sekwencji wydarzeń. Mieszkańcy zbieraja się na placu przed siedzibą władzy - w naszym przypadku przed ratuszem, czyli miejscem urzędowania, stanowienia i egzekwowania prawa oraz przechowywania dokumentów. Następnie często mamy do czynienia z hierarchicznym obchodem - przejściem, przejazdem do miejsca sprawowania władzy, ewentualnie wyjściem, w celu ukazania przedstawicieli władzy zebranej publiczności oraz dokonaniem aktu ich publicznego wywyższenia. Demonstracji towarzyszy wyeksponowanie symboliki sprawowanej władzy (herby, godła, choragwie, insygnia urzędowe, specjalne ubiory) ${ }^{18}$ oraz posiadanej siły (obecność i prezentacja straży lub wojska). Z reguły wygłaszane sa okolicznościowe przemówienia, czemu towarzyszy głośna oprawa muzyczna (fanfary, bębny, okazjonalne kantaty), wznoszenie wspólnych okrzyków na wiwat, znaki dźwiękowe: dzwony, melodie karylionów, saluty artyleryjskie). Sytuacja ceremonialna poza ukazaniem potęgi i powagi władzy służy z reguły publicznemu wynagrodzeniu (niekiedy i upokorzeniu) poprzez wręczenie podarków lub inne okazjonalne formy uhonorowania (upokorzenia), czasem rozdawnictwo pieniędzy, ogłaszanie aktów łaski itp. Sekwencję kończy uroczysta biesiada lub przynajmniej wystawny poczęstunek; począwszy od schyłku XVI w. dziennym uroczystościom radosnym często towarzyszyły zamykające je wieczorne iluminacje oraz pokazy ogni sztucznych ${ }^{19}$.

${ }^{18}$ Zob. przegląd w: B. Stollberg-Rilinger, Zeremoniell, Ritual, Symbol. Neue Forschungen zur symbolischen Kommunikation in Spätmittelalter und Früher Neuzeit, „Zeitschrift für Historische Forschung” 27, 2000, s. 389-405; polski dorobek badań nad insygniami władzy - zob. systematyzujące prace W. Maisla: Archeologia prawna Polski, Warszawa-Poznań 1982, s. 198-270; o ratuszach: s. 95-97; tenże, Archeologia prawna Europy, Warszawa-Poznań 1989, s. 222-316, o ratuszach: s. 74-79.

${ }^{19}$ Przegląd zagadnienia w: M. Wenzel, Eine Kunstform des fernen Ostens? Das Feuerwerk in der europäischen Festkultur der Frühen Neuzeit, „Frühneuzeit-Info” 11, 2000, nr 1, s. 16-26; E. Fähler, Feuerwerke des Barock. Studien zum öffentlichen Fest und seiner literarischen Bedeutung vom 16. bis 18. Jahrhundert, Stuttgart 1974; miedzioryt z projektem pokazu fajerwerków w Gdańsku na cześć Jana III Sobieskiego zamieszczony został w pracy kapitana artylerii E. Brauna, Novissimum Fundamentum et praxis artillerice oder nach jetziger bessten Manier neu vermehrter und ganz 
Trwałym upamiętnieniem szczególnie doniosłych ceremonii publicznych były z reguły dedykowane wydarzeniu lub osobom ze środowiska władzy informacyjne druki: awiza, panegiryki ${ }^{20}$, dzieła malarskie, grafiki, pamiątkowe medale ${ }^{21}$. Ulice zdobiły elementy lekkiej, drewniano-płóciennej architektury ceremonialnej - bramy triumfalne, obeliski ${ }^{22}$, które stanowiły kulisy uroczystości, dodatkowo objaśniające treść inscenizacji parateatralnych, pokazywanych układów „,̇̇ywych obrazów”, demonstracji zręczności szermierczej, prezentacji i defilady rot mieszczańskich itp. Wszystko to tworzyło okazjonalny mecenat artystyczny i rzemieślniczy o skali znacząco ciążącej na budżetach poszczególnych miast ${ }^{23}$.

Organizowane w miastach pruskich uroczystości, nawet gdy były one powiązane z pewnymi elementami liturgii świątecznej (np. nabożeństwa)

gründlicher Unterricht [...], Dantzig 1687, il. po s. 196, 197; to wydanie drugie pracy, pierwsze ukazało się w Gdańsku w 1682 r.

${ }^{20} \mathrm{~Np}$. rozległy tekst recesu: P. Witzke, „Recess undt kurtze Beschreibung alles dessen, was bei der Sigismundi des Dritten [...] glücklichen Ankunfft, Anwesenheit und Abfuhr in und bei dieser Stadt Dantzig ist vergelauffen", APGd., 300, 29/101, k. 48-109. Tekst do literatury wprowadzili: J. Bolte, Das Danziger Theater im 16. und 17. Jahrhundert, Hamburg-Leipzig 1895; oraz T. Witczak, Teatr i dramat staropolski $w$ Gdańsku, Gdańsk 1959; inne odpisy relacji Witzkego: E. Kotarski, Gdańska poezja okolicznościowa XVII wieku, Gdańsk 1993, s. 45, 46, 308, przyp. 18; zob. również: J.M. Krzemiński, Joachima Pastoriusa wiersz o widowiskach w Gdańsku w 1651 roku, w: Od liryki do retoryki. W kregu stowa literatury i kultury. Prace ofiarowane Profesorom Jadwidze i Edmundowi Kotarskim, red. I. Kadulska, R. Grześkowiak, Gdańsk 2004, s. 77-86.

${ }^{21}$ E. Kizik, Gdański medal jubileuszowy z okazji 300-lecia inkorporacji Prus do Polski w 1754 roku, „Zapiski Historyczne” 77, 2012, nr 2, s. 79-91; M. Stahr, Medale Wazów w Polsce 1587-1668, Wrocław 1990.

${ }^{22}$ J. Żukowski, Architektura okazjonalna na uroczystości zaślubin i koronacje Ludwiki Marii Gonzagi w roku 1646, „Biuletyn Historii Sztuki” 73, 2011, nr 1/2, s. 45-92; tenże, „Cnota przewyższasz gockiego Adolfa”. Oprawa artystyczna toruńskiej (1635) i elblaskiej (1636) intrady Króla Jego Mości, w: Polis, urbs, metropolis. Materiały sesji Stowarzyszenia Historyków Sztuki, red. L. Lameński, E. Błotnicka-Mazur, Warszawa 2011, s. 105-124; tenże, Phoenix Alter. Program ideowy pierwszej wizyty Wtadystawa IV w Gdańsku (1634), „Barok” 18, 2011, nr 2 (36), s. 131-173; M. Morka, Arcus Gratiae et Pacis. Gdańska brama triumfalna na wjazd Ludwiki Marii Gonzagi, w: Podtug nieba i zwyczaju polskiego. Studia z historii, architektury, sztuki i kultury ofiarowane Adamowi Miłobędzkiemu, Warszawa 1988, s. 567-579; ogólnie: A. Kurkowa, Gdańska grafika ilustracyjna druków okolicznościowych XVII wieku, Wrocław 1979, s. 158-219; ujęcie problemu na tle europejskim: H. Osiecka-Samsonowicz, Polskie uroczystości w barokowym Rzymie 1587-1696, Warszawa 2012 (tu także podstawowa literatura przedmiotu).

${ }^{23}$ E. Kizik, Koszty pobytu królów...; tenże, Prezenty w polityce Gdańska $w$ XVII-XVIII wieku, w: Prusy i Inflanty między średniowieczem a nowożytnościq. Państwo społeczeństwo - kultura, red. B. Dybaś, D. Makiłła, Toruń 2003, s. 105-116. 
czy np. z pogrzebami, nosiły charakter przede wszystkim świecki i służyły oddaniu honorów przedstawicielom władzy. Również podporządkowanie od połowy XVI w. kościołów luterańskiego i kalwińskiego w Prusach Królewskich radom miejskim znacząco redukowało sakralny wymiar ceremonii publicznych; pozwalało to m.in. na unikanie pewnej niezręczności w związku z odmiennością wyznaniową królów polskich lub ich katolickich reprezentantów (np. biskupów warmińskich, włocławskich czy chełmińskich odbierających w imieniu królów hołdy mieszczan $)^{24}$.

Ceremonie publiczne w wielkich miastach pruskich urządzane były z różnych powodów. Część miała charakter akcydentalny i stanowiła bieżąca reakcję na zaistniałe, często nagłe wydarzenia głośne i znaczące w skali całego państwa lub regionu, jak np. śmierć władcy lub członka królewskiej rodziny, triumf militarny, zawarty pokój; służyły wyrażeniu albo powszechnego smutku i żałoby, albo szczęścia i radości. Inne - powtarzające się wydarzenia cykliczne, jak np. coroczne kiery, obchody jubileuszowe (np. jubileusze stuletnie) - służyły uroczystemu zakomunikowaniu zmiany władzy albo powtórnemu przeżyciu wydarzenia $\mathrm{z}$ przeszłości $\mathrm{w}$ celu zachowania go $\mathrm{w}$ pamięci i świadomości współczesnych.

Święta władzy w wielkich miastach pruskich można podzielić w zależności od zasięgu terytorialnego na:

- ogólnopaństwowe,

- prowincjonalne, pruskie (w skali Prus Królewskich i Książęcych ogólnopruskie lub organizowane jedynie w Prusach Królewskich),

- ogólnomiejskie,

- środowiskowe.

Charakter ogólnopaństwowy przyjmowały organizowane równocześnie $\mathrm{w}$ poszczególnych miastach monarchii obchody związane $\mathrm{z}$ wydarzeniami z życia królów i członków ich rodzin, z historią oraz bieżącymi wydarzeniami państwowości polsko-litewskiej. I były to zwykle planowane na kilka kolejnych dni ceremonie z okazji:

- elekcji oraz koronacji królów polskich,

- wesel, małżeństw, chrztów dzieci królewskich, pogrzebów i żałoby po śmierci królów polskich i członków ich rodzin² ${ }^{25}$

- triumfów militarnych Rzeczypospolitej,

${ }^{24}$ P. Czapiewski, Jak przyjmowali Gdańszczanie biskupów włocławskich, „Zapiski TNT" 2, 1911-1913, s. 21-32.

${ }^{25}$ E. Kizik, Gdańskie uroczystości żałobne po śmierci królów polskich i członków ich rodzin $w$ XVII i w XVIII wieku, w: Pamiętnik XV Powszechnego Zjazdu Historyków Polskich, red. J. Staszewski, Toruń-Gdańsk 1995, s. 291-306. 
- podpisania rozejmów lub pokojów kończących wojny Rzeczypospolitej, np. pokoju w Oliwie w 1660 r.

Niektóre ceremonie państwowe w miastach pruskich odbywały się z udziałem samych władców lub ich przedstawicieli. Należały do nich:

- ceremonialne wjazdy do miast pruskich królów polskich oraz (lub) członków panującej rodziny,

- hołdy składane królom: Polski (lub ich przedstawicielom) ${ }^{26}$, Szwecji (lub ich przedstawicielom) w 1626, 1656, 1703 r., Prus w 1772, 1793 r.,

- uroczystości kapitulacyjne, poddania miasta monarchom polskim i obcym, np. Gdańska Augustowi III w 1734 r., Elblaga (1626), Torunia (1703) - królom szwedzkim oraz władcom pruskim po I i II rozbiorze Polski,

- uroczyste wjazdy władców sojuszniczych, np. cara Piotra I (1709, 1711 r.),

- wydawanie przez królów nadrzędnych aktów prawnych,

- uczestniczenie władców lub ich przedstawicieli w ceremonialnych kaźniach (Gdańsk 1526, 1678 r.).

Charakter ograniczony do środowisk miejskich miały:

- wybory władz miejskich (kiery) ${ }^{27}$,

- wybory władz kościelnych (ordynowanie na urzędy pastorskie w głównych kościołach miasta),

- jubileusze inkorporacji Prus do Polski (1554, 1654, 1754 r. $)^{28}$,

- jubileusze reformacji lub wprowadzenia reformacji w miastach pruskich $(1717,1757$ r.),

- jubileusze założenia miejskich gimnazjów akademickich ${ }^{29}$,

- otwarcie obrad Colloquium Charitativum (Toruń 1645),

- święto na część odparcia oblężenia Szwedów (Toruń 1630),

- uchwalenie wilkierzy miejskich,

- coroczne zawody strzeleckie, gonitwy majowe,

${ }^{26}$ S.M. Sawicka, Hołdy królom polskim z Gdańska i Królewca, „Rocznik Gdański” 7/8, 1933/1934, s. 429-440 (autorka skoncentrowała się na opisie okazjonalnych podarków); H.W. Hoffmann, Danzig huldiget zu letzten Mal, „Weichselland. Mitteilungen des Westpreußischen Geschichtsvereins" 42, 1943, s. 72-76.

${ }^{27}$ Zachował się np. niezwykle ciekawy plan stołu biesiadnego z okazji kiery w 1752 r., APGd., 300,R/G, 28.

${ }^{28}$ Zob. E. Kizik, Gdański medal...

${ }^{29} \mathrm{Na}$ temat jubileuszy gdańskiego Gimnazjum Akademickiego zob. wybór publikacji towarzyszących jubileuszowi 200-lecia, w opracowaniu i tłumaczeniu R. Dzięgielewskiego, w: Gdańskie Gimnazjum Akademickie, t. 3: Wybór źródet od XVI do XVIII wieku, red. Z. Nowak, Gdańsk 2008, s. 115-532. 
- wznoszenie miejsc kaźni i wymierzania kar (ceremonialne przejścia władz miejskich na miejsce straceń i pręgierzy) $)^{30}$,

- charakter lokalnych świąt publicznych nosiły również pogrzeby burmistrzów lub bohaterów (zabitych dowódców obrony Gdańska przed wojskami króla Stefana Batorego w 1577 r., pogrzeb admirała Arndta Dickmana, śmiertelnie ranionego w bitwie pod Oliwa 1627 r., czy - w Elblagu - pogrzeb oficera szwedzkiego Fransa Bernarda hr. von Thurn w 1629 r.),

- ceremonie rozpoczęcia sejmów w Toruniu (1519, 1576, 1626 r.).

Systematyka uwzględnia spisy ceremonii ujętych we wspomnianych wcześniej archiwalnych gdańskich i elbląskich opisach uroczystości miejskich; można dyskutować, czy nie należało dodać również i honorowego wymierzania kary śmierci na placach przed ratuszami ${ }^{31}$. Lecz poza wyżej wspominanymi kaźniami w Gdańsku w 1526 i 1678 r., które stanowiły karę za obrazę majestatu ${ }^{32}$, inne nie wymagały obecności całej władzy miejskiej, ale jedynie sędziego oraz burgrabiego - przedstawiciela króla; nie było również obligatoryjnego uczestnictwa w tych ceremoniach ani mieszczaństwa, ani reprezentantów - np. starszyzny cechowej. Dlatego też odstapiłem od uwzględnienia ich w niniejszych rozważaniach.

\section{Ratusze jako okazjonalne rezydencje władców}

Z prawno-administracyjnego punktu widzenia duże miasta pruskie pozostawały w okresie nowożytnym organizmami złożonymi, wielokrotnymi ${ }^{33}$, czego wyrazem było posiadanie przez poszczególne organizmy miejskie osobnych ratuszów. Niemniej wewnętrzne spory o przywództwo

${ }^{30}$ E. Kizik, Uroczystości przy remontach szubienicy i pręgierzy $w$ Gdańsku od drugiej połowy XVI do poczatku XIX wieku. Przyczynek do dziejów ceremonii publicznych w okresie nowożytnym, „Czasy Nowożytne” 24, 2011, s. 77-89.

${ }^{31}$ Zob. D. Kaczor, Przedstawienia egzekucji i miejsc wymierzania sprawiedliwości w Gdańsku w XVII wieku. Przyczynek do ikonografii prawnej miasta wczesnej epoki nowożytnej, w: Studia z historii sztuki i kultury Gdańska i Europy Pótnocnej. Prace poświęcone pamięci Doktor Katarzyny Cieślak, red. J. Friedrich, E. Kizik, Gdańsk 2003, s. 328-332.

${ }^{32}$ E. Cieślak, Walki społeczno-polityczne $w$ Gdańsku w drugiej połowie XVII wieku. Interwencja Jana III Sobieskiego, Gdańsk 1962, s. 248-251. Z kolei kaźń osób uznanych za odpowiedzialne za tumult toruński w 1724 r. odbyła się na wewnętrznym dziedzińcu ratusza, dlatego też nie nosiła charakteru pełnej ceremonii publicznej.

${ }^{33}$ Przegląd zagadnienia w: M. Słoń, Miasta podwójne i wielokrotne w średniowiecznej Europie, Wrocław 2011. 
polityczne było już rozstrzygnięte i nawet wzniesienie na gdańskim Starym Mieście nowego gmachu ratuszowego w latach 1587-1595 nie zmieniło faktu, że urzędujący tam rajcy nie odgrywali większej roli w mieście. Podstawowe funkcje ceremonialne w całej aglomeracji pełnił ratusz Głównego Miasta ${ }^{35}$ oraz reprezentacyjna przestrzeń uliczna rozciagająca się od Bramy Długoulicznej po Bramę Kogi (ul. Długa i Długi Targ). Podobnie sytuacja wyglądała w Toruniu, w którym funkcje ceremonialne spełniał ratusz Starego Miasta wraz z otaczajacym go rynkiem. Z nieco większej samodzielności korzystało elbląskie Nowe Miasto, jednak znaczenie tamtejszego ratusza w ceremoniach o charakterze państwowym czy nawet regionalnym było niewielkie i dlatego pomijam je w niniejszych rozważaniach.

O randze i znaczeniu ratuszy świadczy wykorzystanie ich na królewskie rezydencje lub choćby miejsca ceremonialnych audiencji w czasie pobytów władców w miastach pruskich. Kwestia pobytu w Gdańsku i Elblagu królów polskich została uregulowana na mocy przywilejów Kazimierza Jagiellończyka oraz ukształtowanego obyczaju z końca XVI w. Gdańszczanie zobowiązali się do zapewnienia królowi i jego całemu dworowi trzydniowego pobytu w mieście na ich koszt oraz utrzymywania królewskiego pałacu: „omnia ad victum regum et aulae totius necessaria". Funkcji rezydencjonalnej nie mogły w wielkich miastach pruskich pełnić dawne zamki krzyżackie, albowiem zostały one bez oglądania się na spodziewany przyjazd króla lub jego przedstawicieli bezzwłocznie zburzone przez zapobiegliwych mieszczan Gdańska, Torunia i Elblaga (1454). Równocześnie Gdańsk oraz Elblagg nigdy nie wywiąały się ze swojego obowiązku hołdowniczego z 16 VI $1454 \mathrm{r}^{36}$ i 24 VIII $1457 \mathrm{r}^{37}$, czyli wzniesienia dla władcy odpowiednich dworów lub pałaców wraz ze stosownymi zapleczami gospodarczymi. Wzajemne targi i kontrowersje o wzniesienie odpowiedniej siedziby w Gdańsku trwały przez 300 lat, a kwestia budowy dworu królewskiego stała się bodajże po raz ostatni przedmiotem kontrowersji w 1732 r., pomiędzy

\footnotetext{
${ }^{34}$ J. Habela, Ratusz Staromiejski w Gdańsku, Gdańsk 1986, s. 28-34.

${ }^{35}$ Zob. M. Bogucka, Funkcje społeczno-polityczne ratusza Głównego Miasta w Gdańsku do końca XVIII wieku, w: Ratusz w miastach..., s. 79-89; J. Zdrenka, Ratusz Głównego Miasta w Gdańsku i jego użytkownicy w okresie od XIV do XIX wieku, w: tamże, s. 91-99.

${ }^{36}$ I. Fabiani-Madeyska, dz. cyt.

${ }^{37}$, „[...] auch sollen sie vns bawen vor vns vnd vnsre Kunigine und nachkomlinge einen Hoff vnd gemach vnd den in wirden halden vnd vns dorine vnd vnser Koeningine vnd nachkomlinge an hoy und holtze versorgen, so wir adir sie hinkomen", cyt. za: L. Neubaur, dz. cyt., s. 115, przyp. 2.
} 
królem Augustem II a burmistrzami gdańskimi ${ }^{38}$. Wydaje się, że August III do tej sprawy już nie nawiązywał ${ }^{39}$. Sam król, rezydujący w klasztorze oliwskim, ostatecznie poirytowany wykrętnymi wyjaśnieniami gdańszczan, którzy wcześniej złożyli hołd Stanisławowi Leszczyńskiemu, odmówił im ceremonialnego wjazdu do miasta i nie dopuścił rajców do ucałowania ręki pańskiej. Władca zamiast wykonać ten pojednawczy gest i wydać akt przebaczenia, celem spacyfikowania niepokornego miasta pozostawił na dwa lata w Twierdzy Wisłoujście garnizon saski.

Brak odpowiedniej siedziby zmuszał królów polskich do korzystania z budynków ratuszowych. W gdańskim Ratuszu Głównomiejskim w latach 1457 i 1468 gościł po kilka tygodni m.in. Kazimierz Jagiellończyk, a w 1504 r. przez dwa tygodnie zamieszkiwał tam król Aleksander ${ }^{40}$. Jednak już towarzyszący królowej Helenie Moskiewskiej fraucymer ulokowany został w domu jednego z burmistrzów. Wiadomo, że $\mathrm{w}$ ratuszu rezydował również Zygmunt I w czasie trzymiesięcznego pobytu w 1526 r. $^{41}$ Od czasu wizyty Zygmunta Augusta (1552) improwizowane rezydencje dla królów i królowych odwiedzających Gdańsk urządzano w kilku sąsiadujących kamienicach przy Długim Targu, które łączono, przebijając drzwi w dzielących je murach ogniowych ${ }^{42}$.

Zupełnie niepozorny i mało przystajacy do pełnienia funkcji reprezentacyjnych był niewielki ratusz elblaski. Najwidoczniej jednak w XVI w. wykorzystywano go dla celów goszczenia znaczniejszych gości ${ }^{43}$, albowiem jeszcze w 1612 r. starano się zagospodarować gmach na przyjęcie Jana Zygmunta, elektora brandenburskiego i regenta pruskiego. Rada o planowanym przybyciu dowiedziała się 10 IX 1612 r. i na odpowiednie prace miała jedynie około $10 \mathrm{dni}^{44}$. Ostatecznie jednak książę zdecydował się na skorzystanie z gościny $\mathrm{w}$ jednym $\mathrm{z}$ patrycjuszowskich domów. Również inni władcy polscy, Zygmunt III (przyjazd wraz z księciem Władysławem w czerwcu 1622), czy szwedzcy - Gustaw Adolf

\footnotetext{
${ }^{38}$ I. Fabiani-Madeyska, dz. cyt., s. 188.

${ }^{39}$ Gdańsk po kapitulacji uznał Augusta III za króla i w niedzielę 11 VII $1734 \mathrm{r}$. odbyły się uroczystości z tej okazji; 2 VIII podkanclerzy i biskup krakowski odebrali w imieniu władcy hołd i przysięgę wierności; E. Cieślak, W obronie króla Stanisława Leszczyńskiego, Gdańsk 1986, s. 155, tam również wskazówki archiwalne.

${ }^{40}$ Chronologię pobytu podaje I. Fabiani-Madeyska, dz. cyt., s. 196-197; M. Bogucka, dz. cyt., s. 82 i n.

${ }^{41}$ I. Fabiani-Madeyska, dz. cyt., s. 145.

42 Tamże, s. 146-148.

${ }^{43}$ Osobiście hołdy w Elblagu odbierali Kazimierz Jagiellończyk w 1454, Olbracht w 1496, Aleksander w 1504 r.; L. Neubaur, dz. cyt., s. 115.

${ }^{44}$ Tamże, s. 116.
} 
(1626), nie wykorzystywali już ratusza elblaskiego w celach rezydencjonalnych. Najpoważniejsi goście zatrzymywali się zwykle w domu Izaaka Speringa, który z powodu uznania jego domu za oficjalną rezydencję przez króla Władysława IV korzystał z przyznanego mu przez radę miejska immunitetu ${ }^{45}$. Z tej kamienicy, która z czasem określano jako „Dom Królewski”, korzystali również przedstawiciele króla polskiego, którzy przybywali do miasta, by odebrać przysięgę hołdowniczą ${ }^{46}$.

Dłużej i częściej służył władcom toruński Ratusz Staromiejski, którego kubatura uległa znaczącemu powiększeniu w początkach XVII w., co umożliwiało dalsze pełnienie funkcji reprezentacyjnych ${ }^{47}$. Spośród miast pruskich najczęściej władców polskich gościł właśnie Torun. Przyjazdy władców polskich do Torunia zwiazane były przede wszystkim z dogodnym położeniem miasta tuż przy granicy pomiędzy Prusami a Korona. Wielokrotnie rezydował w nim dwór króla Kazimierza Jagiellończyka, m.in. w 1454 r., w 1457 r. oraz (dłużej) w czasie rokowań pokojowych w 1466 r. ${ }^{48}$ Po raz ostatni, przez siedem tygodni, Ratusz Staromiejski gościł króla Kazimierza Jagiellończyka w 1485 r. Jego syn i następca Jan Olbracht mieszkał w nim przez kilka miesięcy na przełomie 1494/1495 r., jak również w maju i czerwcu 1501, kiedy to doznał wylewu i częściowo sparaliżowany zmarł 17 VI w jednej z sal budynku (tzw. Królewskiej). Funkcję rezydencjonalną i miejsca audiencji dla posłów moskiewskich i tatarskich ratusz toruński pełnił za czasów króla Aleksandra w 1504 r., a przede wszystkim od grudnia 1519 do 30 IX 1520 r. i od końca stycznia do 25 IV 1521 r., gdy w związku z wojna z Zakonem gościł i urzędował w nim Zygmunt I. Warto jednak wspomnieć, że władcy dzielili pobyty pomiędzy Toruniem a nieodległym zamkiem w Dybowie, gdzie każdorazowo umieszczano też część dworu, służby i innych osób towarzyszacych ${ }^{49}$. W ratuszu rezydowano wszelako aż do schyłku XVII w. Z tradycją zerwał August II, który w związku z planowanym w Toruniu zjazdem senatorów i szlachty przybył niezapowiedziany do miasta (30 X 1702) i lekceważąc witajacych, zatrzymał się kamienicy Waschlegerów. Niemniej oficjalne przywitanie władcy

45 Tamże, s. 119.

${ }^{46}$ Tamże, s, 123-124.

${ }^{47}$ M. Woźniak, Ratusz Staromiejski w Toruniu, w: Ratusz w miastach..., s. 164-165.

${ }^{48}$ Kalendarium wg Królowie polscy $w$ Toruniu..., passim, oraz J.H. Zernecke, dz. cyt., passim.

${ }^{49}$ Zamek po zniszczeniu przez Szwedów w 1656 r. stracił swoje znaczenie rezydencjonalne. M. Rzeczkowska-Sławińska, I. Sławiński, Zamek dybowski w świetle źródet historycznych, architektonicznych i ikonograficznych, w: Zamek dybowski archeologia, historia, przyszłość, red. L. Grzeszkiewicz-Kotlewska, L. Kotlewski, T. Zakrzewski, Toruń, 1999, s. 17-60. 
wraz z przekazaniem mu kluczy do miasta odbyło się w dniu następnym właśnie w ratuszu. W trakcie kolejnego dłuższego pobytu króla w Toruniu (listopad 1702 - luty 1703) ratusz również nie stał się oficjalną rezydencją władcy. Wkrótce, zresztą wskutek bombardowania miasta przez Szwedów 24 IX 1703, budynek uległ zniszczeniu; odbudowa ciagnęła się z przerwami przez trzy dekady.

Rola toruńskiego Ratusza Staromiejskiego była wyjątkowa. Ratusze gdański i elblasski - jak podkreślono wyżej - już w XVI w. utraciły swoje znaczenie jako oficjalne rezydencje królewskie. Znajdywało to również swój dobitny wyraz w sposobie sytuowania okazjonalnych dekoracji (piramid, bram triumfalnych) wznoszonych ku czci królów i ich małżonek; sytuowano je nie przy ratuszach, lecz właśnie naprzeciwko improwizowanych siedzib królów. Znamienne, że nawet ceremonialne uczty nie odbywały się w gdańskim ratuszu, lecz np. w Bramie Zielonej (przyjęcia na cześć królowej Ludwiki Marii w 1646 r.). W Gdańsku istotne miejsce $\mathrm{w}$ obchodach ceremonialnych pełniła w XVII-XVIII w. twierdza w Wisłoujściu, do której przewożono oficjalnych gości łodziami; $\mathrm{w}$ pomieszczeniach twierdzy organizowany był bankiet, zaś wznoszonym toastom towarzyszyły saluty artyleryjskie. Zwiedzanie fortalicji poza funkcjami ceremonialnymi i ludycznymi stanowiło również oczywistą demonstrację siły miasta, zdecydowanego na zbrojne wystapienie $\mathrm{w}$ obronie swoich praw $^{50}$. Również przeciwko władcom polskim, gdyby zostali uznani za tyranów.

Rzecz jasna poza najważniejszymi względami praktycznymi - ciasnota, brakiem odpowiednich wygód, nie wspominając o uciążliwości i zamieszaniu związanych z koniecznością czasowego wyłączenia części pomieszczeń ratuszowych z bieżących funkcji urzędowych - generalnie stare budynki ratuszowe często okazywały się słabo dostosowane do wymogów nowej renesansowej etykiety dworskiej oraz konieczności pomieszczenia licznych urzędników królewskich. Również i podkreślany przez Marię Bogucką aspekt symboliczny wpływał na zmianę preferencji władców w XVI w. Chodzi mianowicie o znaczący wzrost aspiracji pewnych pozostajacych $\mathrm{w}$ bliskich stosunkach $\mathrm{z}$ władcami patrycjuszy gdańskich, którym goszczenie dworu przynosiło dodatkowy splendor i, co najmniej, wyższą pozycję w elicie miasta. Z drugiej strony, na zmianę siedziby mogły również wpływać sprzyjające republikańskim aspiracjom Gdańska polityczno-prawne relacje pomiędzy rada miejską Gdańska a władzami państwa.

${ }^{50}$ E. Kizik, Odwiedziny Twierdzy Wistoujście w XVII i XVIII wieku, w: Fortyfikacje Gdańska, red. G. Bukal, Gdańsk 2006, s. 119-125. 
Ratusze zachowały jednak część funkcji ceremonialnych, wychodzących poza codzienną rutynę życia miejskiego. Największe sale ratuszowe mogace pomieścić nie tylko wszystkich członków władz miejskich, lecz i oficjalnych gości, spełniały funkcję izb audiencyjnych, służąc przyjmowaniu urzędników państwowych oraz ambasadorów składających oficjalne wizyty $\mathrm{w}$ wielkich miastach pruskich. W salach tych, podobnie jak w pozostałych miastach polskich, pojawiły się galerie portretów królów polskich ${ }^{51}$, ale też obrazy historyczne z dziejów Polski i Prus ${ }^{52}$. Te dekoracje, poza podkreśleniem królewskiego patronatu, służyły często symbolicznej manifestacji niezależności miast od decyzji Sejmu, którego kompetencje w Prusach Królewskich były kwestionowane.

\section{Ratusze w ceremoniach hołdowniczych}

Jedną z najważniejszych uroczystości miejskich były hołdy składane władcom przez rady miejskie i wszystkich mieszczan. Ceremonie hołdownicze organizowano w niedziele lub inne dni świąteczne. Wymagano przy tym bezwzględnej obecności wszystkich mieszczan, tak było zarówno gdy Elbląg złożył hołd Gustawowi Adolfowi, który zajął miasto

${ }^{51}$ Pomocne sa prace historyków sztuki pozwalające przynajmniej na częściowa rekonstrukcję dawnych wnętrz ratuszowych: J. Flik, Poczet królów polskich w Muzeum Okregowym $w$ Toruniu $w$ świetle prac konserwatorskich, „Rocznik Muzeum w Toruniu” 2, 1966, nr 1-2, s. 9-24; J. Flik, B. Herdzin, Poczet królów polskich w zbiorach Muzeum Okregowego w Toruniu, Toruń 2000; Gdańsk dla Rzeczypospolitej. W stużbie Króla i Kościoła [katalog wystawy], red. T. Grzybkowska, Gdańsk 2004; T. Domagała, Kolekcja portretów królewskich z Wielkiej Sali Wety Ratusza Głównego Miasta w Gdańsku, w: Ratusze w miastach..., s. 121-133; zob. syntetyczny artykuł A. Bartetzkiego, Miasto a Rzeczpospolita. Watki polityczne dekoracji ratuszowych $w$ Polsce $w$ okresie wczesnonowożytnym, „Polska Akademia Umiejętności. Prace Komisji Środkowoeuropejskiej” 7, 2000, s. 113-126; tam również przegląd literatury; tenże, Die Beziehungen zwischen Stadt und Krone im Spiegel von Rathausdekorationen des Spätmittealters und der frühen Neuzeit (Prag, Breslau, Krakau, Posen), w: Krakau, Prag und Wien. Funktionen von Metropolen im frühmodernen Staat, red. M. Dmitreva, K. Lambrecht, Stuttgart 2000, s. 45-58, 373-385. Dla innych miast, Lublina i Piotrkowa, zob. K. Gombin, Trybunat koronny. Ceremoniat i sztuka, Lublin 2013, s. 95-110, 113.

${ }^{52}$ J. Ruszczycówna, „Bitwa pod Grunwaldem”, nieznany obraz Krzysztofa Boguszewskiego, w: Muzeum i twórca. Studia z historii sztuki i kultury ku czci prof. dr. Stanistawa Lorentza, Warszawa 1969, s. 445, 456-457; Z. Kruszelnicki, Historyzm $i$ kult przeszłości $w$ sztuce pomorskiej, Warszawa-Poznań-Toruń 1984, s. 125-128; tenże, $Z$ zagadnień tematyki pomorskiej $w$ sztuce polskiej od końca XVIII do połowy XX w., „Gdańskie Studia Muzealne” 5, 1989, s. 9-36. 
w 1626 r. ${ }^{53}$, jak i po zakończeniu okupacji, gdy 15 I 1636 r. przysięgę mieszczan na wierność królowi Władysławowi IV odebrali jego komisa$\mathrm{rze}^{54}$. Dla tych celów wzniesiono przed ratuszem specjalne podwyższenie - theatrum, gdzie pod baldachimem zasiedli reprezentanci króla. Miesiąc później Władysław IV uroczyście wjechał do miasta ${ }^{55}$. Osoby, które nie przybyły na hołd publiczny, zostały zobowiązane do uczynienia tego osobiście w wyznaczonym terminie celem dopełnienia leżącego na nich obowiązku. Kara za niezłożenie stosownego podpisu było pozbawienie prawa miejskiego. Nie inaczej było w Gdańsku, gdy na uroczystość złożenia hołdu przedstawicielowi króla Jana III Sobieskiego rada miejska nakazała przyniesienie chorych w lektykach, starców na fotelach ${ }^{56}$.

Sale toruńskiego ratusza, inaczej aniżeli w Gdańsku i Elblagu, regularnie gościły królewskich biesiadników. I to nie tylko polskich, albowiem po kapitulacji miasta i uroczystym wjeździe Szwedów do Elblaga rajcy wydali bankiet na cześć króla Karola X Gustawa, jego brata księcia Adolfa Jana i osób towarzyszacych (5 XII 1655 r.). W tymże ratuszu 1 I 1659 r. przysięgę wierności od skruszonych mieszczan przyją król Jan Kazimierz - uroczystość zakończyła się bankietem i stosownym muzykowaniem.

Na zakończenie warto się nieco skupić na stosunkowo dobrze udokumentowanych ceremoniach hołdowniczych w Gdańsku w XVII i XVIII w. ${ }^{57}$ Od czasów panowania Zygmunta III odbywały się one wedle podobnego scenariusza, dlatego pomijając szczegóły pokrótce omówię scenariusz ostatniej przysięgi złożonej przez gdańszczan królowi polskiemu. Uroczystość odbyła się bez mała w rok po elekcji Stanisława Augusta Poniatowskiego ${ }^{58}$, w niedzielę 26 VI 1765 r. ${ }^{59} \mathrm{~W}$ imieniu króla akt

${ }^{53}$ Uroczysty wjazd Gustawa Adolfa do miasta nastapił 16 VII, hołd mieszczanie złożyli 26 VIII, N. Drabiński, Z dziejów okupacji szwedzkiej Elblaga w latach 1626-1635, „Rocznik Elblaski” 2, 1963, s. 152; opis zamieszcza I. Hoppe, Geschichte des ersten schwedisch-polnischen Krieges in Preußen, red. M. Toeppen, w: Die Preußischen Geschichtsschreiber des XVI und XVII Jahrhunderts, t. 5, Leipzig 1887, s. 74-75, 90-93 (interesujące, że król szwedzki spotkał się z przedstawicielami miasta nie w ratuszu, lecz kamienicy, w której trzy lata wcześniej zatrzymał się król Zygmunt III).

${ }^{54}$ I. Hoppe, dz. cyt., s. 543-544.

55 Tamże, s. 552 i n., tam również (aneks, nr 83, s. 734-735) opis bramy triumfalnej postawionej naprzeciw kamienicy Izaaka Speringa, w której urządzono królewską rezydencję.

${ }^{56}$ APGd., 300, R/K, 4, s. 109.

${ }^{57}$ APGd., 300, R/K, s. 90-116.

${ }^{58}$ Zob. M. Czerniakowska, Gdańskie echa elekcji i koronacji króla Stanistawa Augusta, „Wiek Oświecenia” 15, 1999, s. 257-268.

${ }^{59}$ APGd., 300, R/K, s. 110-116. 
hołdowniczy przyją biskup włocławski Antoni Kazimierz Ostrowski60. Rada wzorem minionych ceremonii (,nach dem Beyspiel voriger Zeiten”) przygotowała kwatery dla poselstwa królewskiego w kamienicach na Długim Targu. Na spotkanie komisarzy królewskich do podgdańskiego Pruszcza wyprawiono sekretarza rady Gabriela Joachima Weickhmanna wraz z rotmistrzem i 32 kawalerzystami z gdańskiego garnizonu. Przy wjeździe do miasta 25 VI delegacje powitał salut artyleryjski z 30 dział ustawionych na wałach miejskich. W dniu hołdu mieszczanie oczekiwali na uroczystość wezwani półgodzinnym dzwonieniem z kościoła Mariackiego do stawienia się na Długim Targu. Stu przedstawicieli Trzeciego Ordynku wraz z członkami pozostałych ordynków wypełniło szczelnie Wielką Salę Sądu Wetowego. Biskup Ostrowski przybył do ratusza karetą i po powitaniu przez członków rady na najwyższym stopniu schodów został poprowadzony do Sali Wety, gdzie znajdowała się galeria portretów królewskich ${ }^{61}$. Zajął miejsce, które w czasie kiery przysługiwało burgrabiemu, czyli przedstawicielowi królewskiemu w mieście. Jego fotel umieszczony był na podwyższeniu, po lewej stronie zasiedli towarzyszący komisarzowi urzędnicy, zaś członkowie Szerokiej Rady przycupnęli na ławkach, oddzielnie rajcy, ława i przedstawiciele pospólstwa. Porządek zasiadania członków ordynków był taki jak w czasie wyborów burmistrzów. Obok miejsca komisarza pod baldachimem umieszczono portret (Brustbild) króla Stanisława Augusta. Po wygłoszeniu przez biskupa Ostrowskiego po łacinie okolicznościowej mowy do członków Szerokiej Rady oraz odpowiedzi syndyka (Gottfrieda Lengnicha) członkowie ordynków na stojąco po kolei składali przysięgę. Następnie komisarz królewski został poprowadzony przez pierwszego burmistrza do okna ratuszowego celem zajęcia miejsca $\mathrm{w}$ fotelu na odpowiednim podwyższeniu. Zebrani przed ratuszem po zdjęciu nakryć głowy powtarzali za sekretarzem słowa roty. Po odebraniu przysięgi biskup powrócił na swoje miejsce. Gdy ceremonia się zakończyła, burmistrzowie odprowadzili królewskiego komisarza na schody wejściowe, skąd udał się on do swojej siedziby. W momencie opuszczania przez niego ratusza rozbrzmiewała muzyka, zaś z wałów miasta oddano salut z 30 armat. W dniu następnym komisarza królewskiego podjęto bankietem w salach Twierdzy Wisłoujście.

\footnotetext{
${ }^{60}$ Jest to bodajże jedyna uroczystość hołdownicza w Gdańsku, która doczekała się ikonografii z epoki. Zob. edycję źródłowa: Księga gdańskiego bractwa butkarzy i ciastkarzy $z$ lat 1724-1768, oprac. i wyd. Z. Kropidłowski, Gdańsk 2010.

${ }^{61}$ T. Domagała, dz. cyt., s. $126-127$.
} 


$$
* * *
$$

Kształtowane przez cały okres nowożytny formy zachowań ceremonialnych w wielkich miastach Prus Królewskich uległy raptownej zmianie po włączeniu prowincji do monarchii pruskiej wskutek rozbiorów Polski. Poza odrzuceniem rytuałów i symboliki odzwierciadlającej charakterystyczny i szczególny stosunek pomiędzy republikańskimi radami miejskimi Gdańska, Elblaga i Torunia a państwowością polska, stopniowo w XIX w. ulegała zniszczeniu część dawnego wyposażenia ratuszowego. Jeśli nie było to skutkiem pożarów, jak w Elblagu w 1777 r., to wynikało z zaniechania czy celowych działań na fali narastającej od połowy XIX w. niechęci do polskich akcentów w historii miast pruskich. Obecnie jedynie kompleksowe, a przede wszystkim interdyscyplinarne badania moga pozwolić na zrekonstruowanie i odpowiednią interpretację tego interesującego rozdziału kultury.

\section{Bibliografia}

Fabiani-Madeyska I., Gdzie rezydowali w Gdańsku królowie polscy?, Gdańsk 1976.

Fabiani-Madeyska I., Palatium regium $w$ Gdańsku, „Rocznik Gdański” 15/16, 1956/1957, s. $140-198$.

Falcke J., Studien zum diplomatischen Geschenkwesen am brandenburgischpreußischen Hof im 17. und 18. Jahrhundert, Berlin 2006 (Quellen und Forschungen zur Brandenburgischen und Preußischen Geschichte, 31).

Gugler A., Feiern und feiern lassen. Festkultur am Wiener Hof in der zweiten Hälfte des 16. und der ersten Hälfte des 17. Jahrhunderts, „Frühneuzeit-Info" 11, 2000, nr 1, s. 68-176.

Kizik E., Koszty pobytu królów polskich w Gdańsku w XVII w. Rekonesans badawczy, KH 114, 2007, nr 4, s. 61-77.

Królowie polscy $w$ Toruniu, red. M. Biskup, Torun 1984.

Neubaur L., Zur Geschichte des sogenannten Königshauses in Elbing, „Zeitschrift des Westpreussischen Geschichtsvereins" 59, 1919, s. 115-133.

Ratusz w miastach pótnocnej Europy. Materiaty z sesji „Ratusz w miastach nadbattyckich”, Gdańsk 23-25 XI 1993, red. S. Latour, Gdańsk 1997.

Stollberg-Rilinger B., Zeremoniell, Ritual, Symbol. Neue Forschungen zur symbolischen Kommunikation in Spätmittelalter und Früher Neuzeit, „Zeitschrift für Historische Forschung" 27, 2000, s. 389-405.

Weller T., Theatrum Praecedentiae. Zeremonieller Rang und gesellschaftliche Ordnung in der frühneuzeitlichen Stadt. Leipzig 1500-1800, Darmstadt 2006. 


\section{Edmund Kizik}

Town halls in large towns in Royal Prussia on public holidays in the 16th-18th century. Marginal notes on the research project

\section{(Summary)}

This text was written as marginal notes to a research project, the aim of which is a comprehensive reconstruction of public ceremonies in large towns of Royal Prussia from the 15th to the early 19th century. Based on literature on the subject and archival sources and old texts, the author, after undertaking an initial characterization of public ceremonies in Prussian towns, focused on the role of town halls as centres for organizing these ceremonies. The ceremonial role of town halls in the early day of their being annexed to Poland increased, as the former centres of authority - the Teutonic castles - were completely destroyed by the townspeople in the year of Prussia's incorporation into Poland (1454), which prevented their being used as residences of the Polish kings. At the same time, the municipal councils of Gdańsk and Elblag, despite the commitments made, failed to actually build royal residences within their walls. The issue of not erecting a royal residence in Gdańsk - the most important Prussian town - continued with varying intensity for more than 300 years until the town joined the Kingdom of Prussia as a result of the second partition of Poland (1793).

In such a situation, when Polish royalty visited the towns, they were accommodated in the town halls which fulfilled the role of substitute residences. However, the town halls in Gdańsk and Elblag, due to lack of space, inadequate infrastructure and changes in the ceremonial etiquette from the second half of the 16th century, ceased to act as royal residences. From that time onwards residences were improvised for royalty and their courts in the adjacent townhouses of the patricians, which were rented out and adapted for that purpose. It was only in Torun, that the large town hall, extended in the 17th century, performed the function of a royal residence until its destruction as a result of being bombarded by the Swedes in 1703 .

The town halls however retained part of their state ceremonial functions. The largest rooms, which could accommodate not only all the members of the municipal authorities but also official guests, were used as audience halls, to receive representatives of the king and ambassadors on diplomatic visits. In these rooms, as in other royal towns, galleries were established with portraits of Polish kings as well as paintings depicting the history of Poland and Prussia. Apart from highlighting the royal patronage, the symbolism of the painted decorations was also used to manifest the towns' independence from the decisions of the Sejm (Parliament), whose competencies were questioned in Royal Prussia.

The most important and well-documented ceremonies in which the town halls played a central role were those which involved paying homage to newly-crowned Polish kings. In the 17th and 18th centuries the bishops of 
Włocławek, who represented the king, usually received homage on behalf of the ruler, whose presence was symbolically marked by a painting of him propped up on an elevated throne. If members of the council and the rank and file met in the main rooms of the town hall, the remaining townspeople gathered on the market square near the town hall. From the beginning of Sigismund III Vasa's rule, the ceremony of paying homage proceeded in a manner which remained unchanged until the end of the Early Modern period of the Polish state.

Key words: Royal Prussia, public ceremonies/celebrations, town halls, royal residences 